\title{
THE DISCOURSE OF A LARGE SCALE ORGANIZATIONAL TRANSFORMATION: THE REENGINEERING OF IBM, 1989-1994
}

\author{
Emmanuel Monod \\ University of Nantes \\ Nantes \\ France \\ Duane Truex \\ Florida International University \\ Miami, Florida \\ U.S.A. \\ Richard Baskerville \\ Georgia State University \\ Atlanta, Georgia \\ U.S.A.
}

\begin{abstract}
Stakeholder agency theory helps to identify six forms of discourse in a case of organizational transformation. These discourses arise in the relationship between actors and six other organizational dimensions: stakeholders, management systems, performance management, IS development methods, organizational transformation methods, and the target structure of transformation. An analysis of the executive discourse in this case exposes the process by which voices from other discourses are heard during organizational transformation.
\end{abstract}

\section{INTRODUCTION}

Organizational change and the related role of information technology (IT) as provocateur of this change are prominent subjects in the information systems

The original version of this chapter was revised: The copyright line was incorrect. This has been corrected. The Erratum to this chapter is available at DOI: 10.1007/978-0-387-35634-1_28 
(IS) discipline. Practicing managers have sought to transform organizational structure in order to move "beyond bureaucracy" (Bennis 1993) and toward "lateral and flexible organizations" (Galbraith 1994). The target structure of that transformation could be an "adhocracy" (Toffler 1970) or an "innovative structure" (Mintzberg 1979). These normative descriptions provide little help in understanding the essential discourse that drives such transformations.

For example, from 1991 through 1993, IBM was hemorrhaging cash. For the first time in its history, it had slipped from a position of absolute market dominance and profitability and had lost more than $\$ 11$ billion U.S. despite having cut more than a third of its global workforce. The board of directors responded by replacing the current $\mathrm{CEO}$ with an outsider to IBM who promptly declared that he was the advocate of the shareholders and that things would change. The urgent requirement that IBM return to profitability justified a reduction in force of almost 150,000 people worldwide, the sale of assets and plants, and a substantial restructuring of the organization from the top down. What followed was a discourse of required radical transformation at IBM.

For the purposes of this paper, a discourse may be considered as an intention of a subject to communicate with an intended audience. This first view is called the psychological interpretation of discourse as introduced by Schleiermacher in Hermeneutics: The Handwritten Manuscripts (1977) in which he analyzes Aristotle's De Interpretatio. This definition is consonant with a classical analysis of literature in which the text is considered to be the result of the intention of the author to communicate with a reader. This is true also of traditional management in which an executive presents a discourse about strategy or corporate results through plans, reports, and other explicit statements of management intention (Ansoff 1962). As a further example, in IS development, the functional view of a requirement may be considered a discourse in which a user (subject) communicates intentions to the developer (agent) (Davis 1982; Sommerville and Sawyer 1997).

There is another way to consider discourse in which the authorship of the text is less important than the influence of language and civilization. This is called grammatical interpretation. Again this approach is from Schleiermacher and his references to Homer's Iliad and Odyssey. This second view describes a sociology of language in which the subject may disappear (Derrida 1978, 1982). The subject is replaced by a wider context including the author's role or social position and in which power is expressed through rules and norms (Foucault 1972). In this sense grammatical interpretation gives way to contextual interpretation. In this characterization, the subjectivity of the author is replaced by "an obscure set of anonymous rules" (Foucault 1972, p. 210).

The typical discourse regarding organizational transformation is a kind of psychological interpretation in which management is portrayed as a rational actor choosing to design, control, and manage organizational change through the 
redesign of organizational process and the implementation of information technology (Nadler and Tushman 1988). But this psychological interpretation can be completed by a contextual interpretation where the management discourse itself is shaped by other forces that can be linked to the views and behaviors of other organizational actors. Using agency theory (Jensen and Meckling 1976) the behavior of a management as an organizational actor can only be understood by considering it to be an agent serving on behalf of one external actor called the primary, e.g., the shareholder. An alternative version of agency theory is stakeholder agency theory (Hills and Jones 1992). It holds that management is an agent that serves a larger set of stakeholders not only including shareholders, but also customers, employees, suppliers, and even local communities. In this theory, local communities are the advocates of issues such as the environment, the quality of life, urbanization, schools, and other community infrastructures and the like. Stakeholder agency theory allows that there exist multiple relevant and valid narratives that describe an organizational transformation. It allows that knowledge and political interests that are often beyond the creator of the discourse can shape the narrative through a privileging process. For example, if the narrator privileges profit, then the knowledge and political interests of the finance function will shape the narrative. As another example, if the narrative's creator privileges growth, then the knowledge and political interests of the operational managers will shape the narrative. In this way, the narrative emerges as actors seek to impose organizational structures and performance measures that best serve their own interests (Mintzberg 1979).

In order to understand how this discourse emerges, we use stakeholder agency theory to identify six forms of discourse in a case of organizational transformation. These discourses arise in the relationship between actors and five other organizational dimensions: stakeholders, management systems, performance management, IS development methods, and organizational transformation methods (see Figure 1). We will then illustrate the practical value of this framework through an analysis of the executive discourse in the IBM case and expose the process by which voices from other discourses are either heard or silenced during organizational transformation.

\section{DISCOURSES IN ORGANIZATIONAL TRANSFORMATION}

The following seven organizational dimensions encompass a linkage between the discourse about organizational transformation through IT and the theoretical elements of organizational structure. There is also an important link with IS development methods and organizational transformation methods. Each of these dimensions is represented in Figure 1 and described thereafter. 


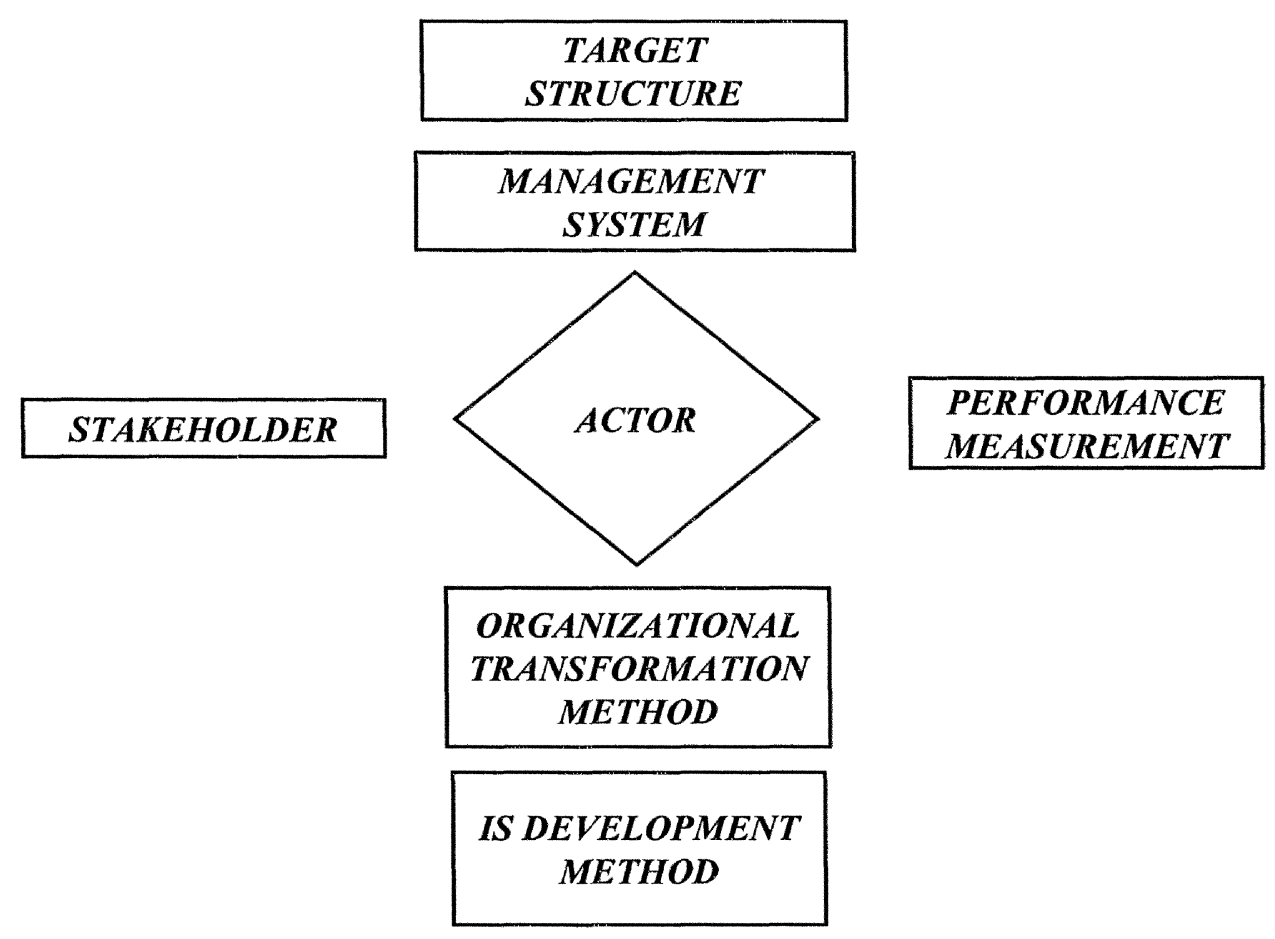

Figure 1. The Research Question

\subsection{Actors and Stakeholders}

The theory of organizational actors (Mintzberg 1979) describes five types of actors: analysts, professional, executive, middle managers, and experts. The three last categories may be simply called managers. In agency theory, only the middle managers (as for instance in the case of IBM, geographical and product divisions heads) and executives correspond to the agent. However, the analysts, who include accountants, controllers, auditors, consultants, and planners, may also be recognized as advocates of the shareholders and thus may be considered agents in the same sense. The professionals are advocates of the employees because as employees themselves they view themselves in dual roles; namely, as actors and stakeholders. The case of the experts is a bit more complex. They are project managers, R\&D managers, entrepreneurs, or change agents of the enterprise. The theory of innovative structure (Mintzberg 1979) says managers must also represent high-performance employees as innovators or intrepreneurs. So by extension, one can claim that these actors represent the customer's interests as well. But they also represent high-performing employees because they are themselves high-level professionals. The last organizational actors, the executives, are supposed to be held to a higher standard. The executives are the agent of all others stakeholders (Hills and Jones 1996). Because shareholders hire (and dismiss) executives, it is not surprising that managers are attentive to 


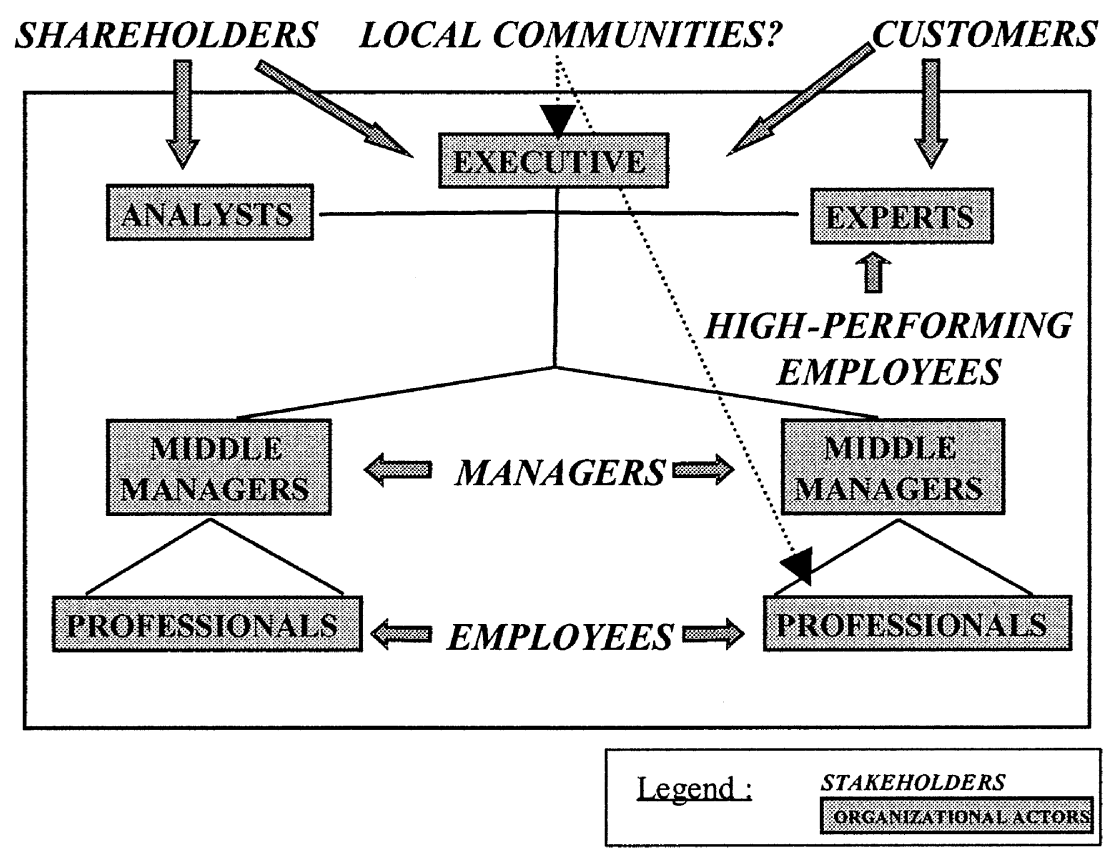

Figure 2. Organizational Actors and Stakeholders Represented

these stakeholders, but as managers, they should also represent the interests of the customers. And, as the most powerful organizational actors and as insiders within the nexus of decisions, they should be the actors in advocating for the local communities (Figure 2). However, as we shall see this is not often the case.

\subsection{Actors and Structures}

Mintzberg's theory has the potential to bridge the gap between organizational stakeholders and their knowledge interests via various organizational forces, coordination modes, and organizational structures. Mintzberg offers a typology of coordination mechanisms that take into account the ideas of Cohen et al. (1972) on how organizational actors impose power. Through this typology, we see how organizational actors try to influence or impose coordination mechanisms that are most favorable for them. In Mintzberg's initial presentation of this typology, the interests of local communities are not considered (see Figure 3). However in later work (Mintzberg 1989), he adds a sixth organizational structure that he terms the missionary structure. This structure, inspired by Japanese enterprise, has an important sense of mission, and of citizenship, both concepts that can be interpreted as a contribution to local communities. 


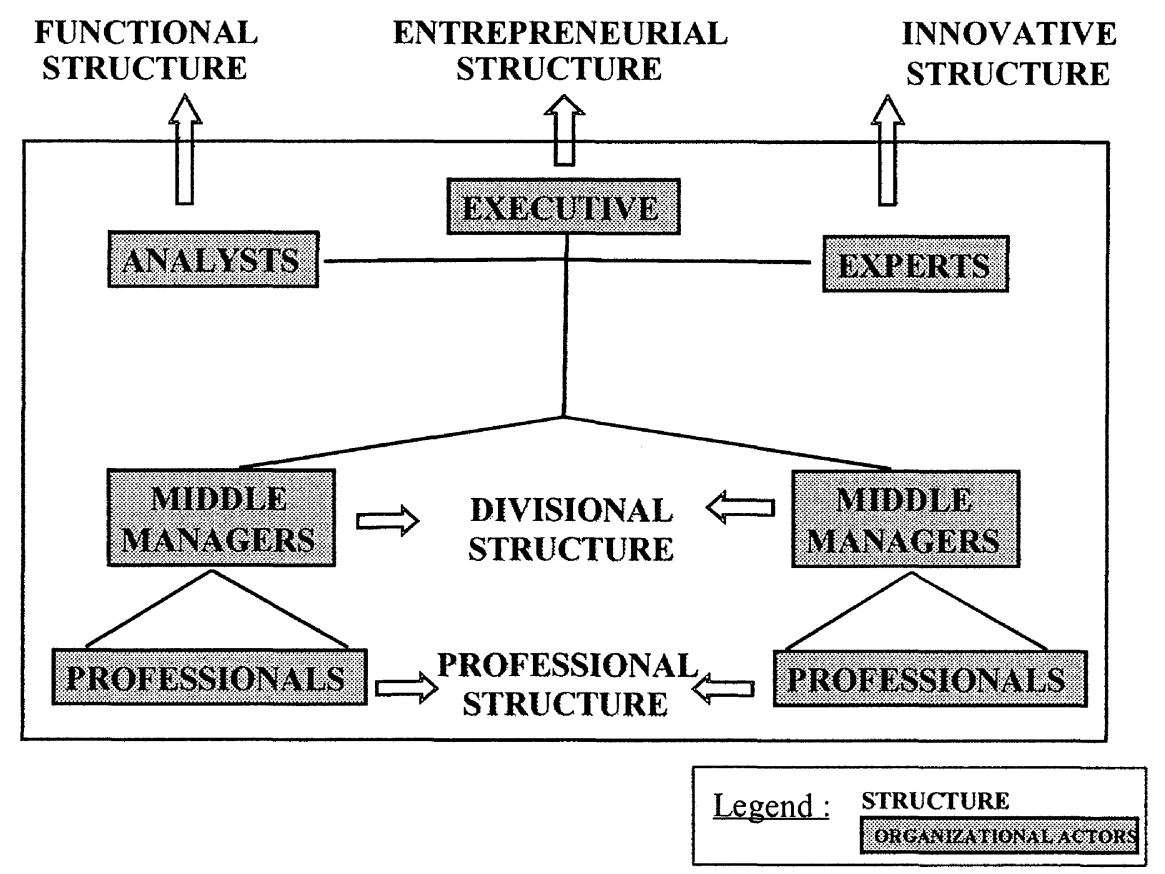

Figure 3. Organizational Actors and Claimed Organizational Structures

\subsection{Actors and Management Systems}

Two dimensions can be used in the representation of organizational structure. The first is centralization $v s$. decentralization of power, an important distinction in classical organization theory (Chandler 1962). The second represents management systems as being organic versus mechanistic (Mintzberg 1979; see Figure 4.) These dimensions help characterize the degree of participation (Burns and Stalker 1961) and of hierarchy. A mechanistic management system, for instance one coordinating through rules and plans, is much more hierarchical than an organic management system that uses face-to-face coordination through ad hoc meetings. This seems to hold whether the organization is centralized or decentralized (Galbraith 1977).

Through this dichotomy it is possible to link each actor to their preferred structure as to the stakeholder represented. Leaving aside missionary structures for the moment, we propose a representation of the preferred management system (and decentralization) for each actor and stakeholder as presented in Figure 5. 


\section{MANAGEMENT SYSTEM}

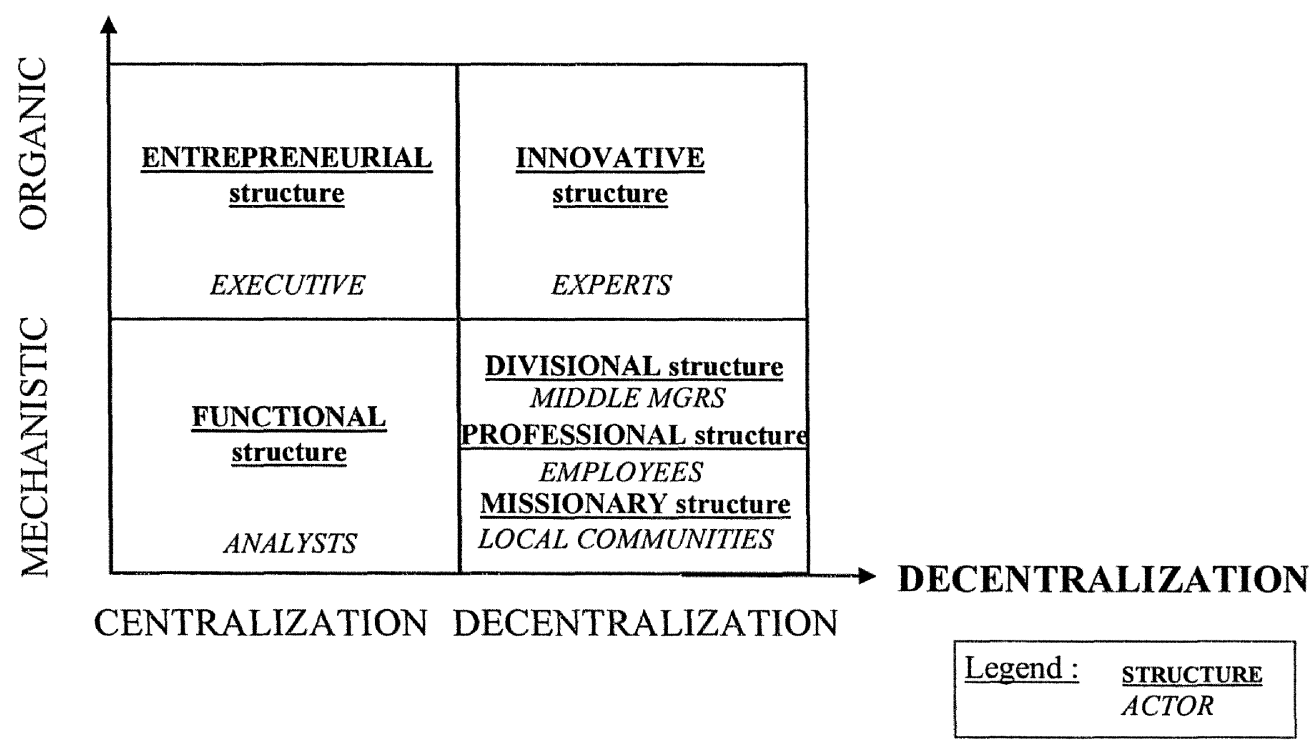

Figure 4. Structure, Actors, Decentralization and Management System

\section{MANAGEMENT SYSTEM}

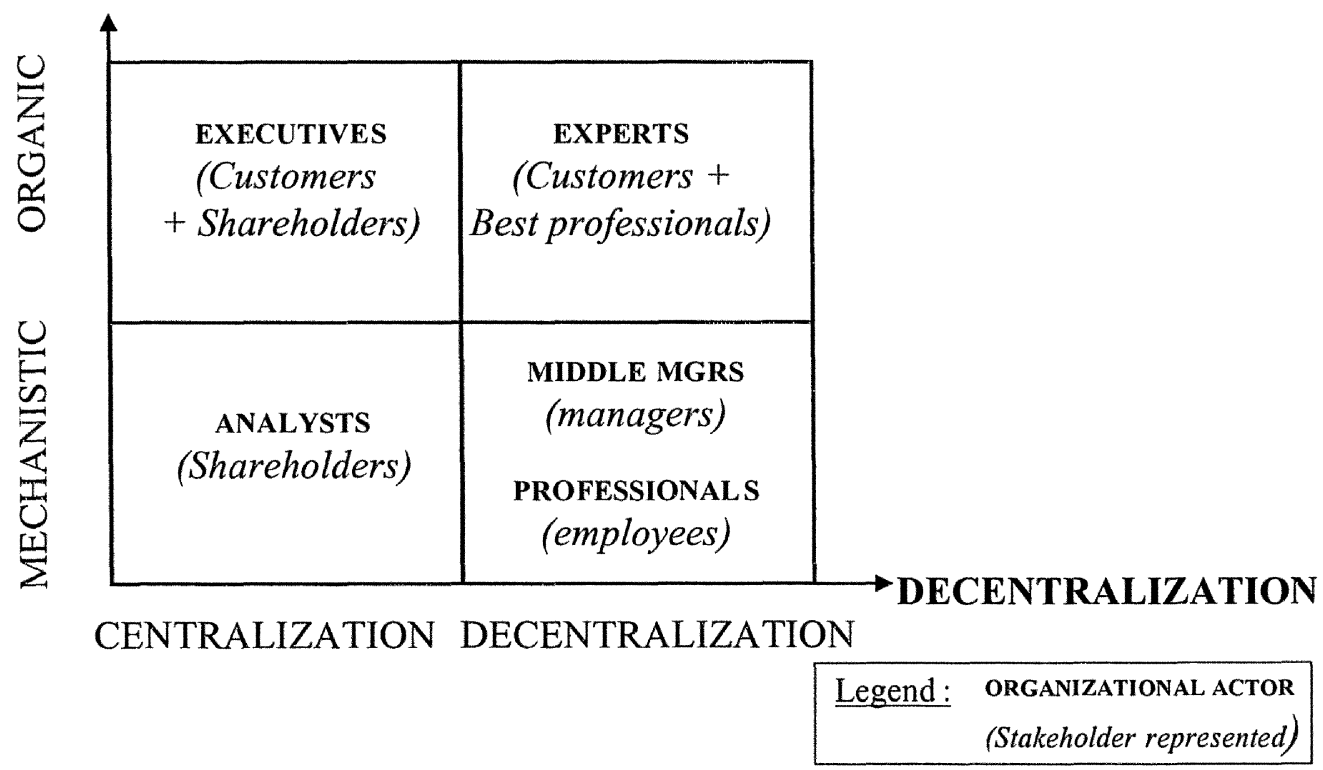

Figure 5. Actors, Stakeholder, Decentralization and Management System 


\subsection{Actors and Performance Measurement}

Structure is also linked to performance measures. For instance, analysts prefer functional structures and see bureaucracy as the most efficient structure because they see cost reduction as the prime performance measure. For them, cost reduction is performance. This illustrates how, as mentioned earlier, each actor and each stakeholder will have differing interests and performance measures. It has been pointed out that a contradiction exists between the espoused goal and performance between shareholders and management in agency theory (Jensen and Meckling 1976). That contradiction relates to performance measures preferred by senior managers as compared to those preferred by stockholders. Where stockholders prefer higher profit and share prices, managers prefer growth. To escape the gazing eye of owners, top management will often privilege growth, with its concomitant increased complexity and diversity, in part to allow less inhibited management freedom. Enlarging this view to stakeholder agency theory (Hills and Jones 1992), the employees are more interested in growth than in profit because growth helps assure wage and job security. They may also be interested in organizational learning in order to have access to continuing education and knowledge management, thus improving their own marketability and hence security. Local communities, as actors, also should be interested in growth, because they benefit from employment.

However, with regard to performance measures, the position of executives and experts is more complex. The experts, as innovators, must be oriented toward an adaptation to the environment, whether it is a competitive advantage or organizational learning (Argyris et al. 1990; Argyris and Schön 1978; Galbraith 1994). The executive, who is supposed to be the agent of all the other stakeholders, must take in account every type of performance measurement. The net of this milieu is that while managers and shareholders focus on productivity, the other stakeholders prefer flexibility because of the importance they place on the organization's adaptation to its environment (Table 1).

Table 1. Actors, Stakeholders, Performance Measurement and Performance Type

\begin{tabular}{|l|l|l|l|l|l|}
\hline $\begin{array}{c}\text { Organizational } \\
\text { Actors }\end{array}$ & \multicolumn{1}{|c|}{$\begin{array}{c}\text { Middle } \\
\text { Managers }\end{array}$} & \multicolumn{1}{|c|}{ Analysts } & Executives & \multicolumn{1}{|c|}{ Experts } & Professionals \\
\hline $\begin{array}{l}\text { Stakeholder } \\
\text { represented }\end{array}$ & Managers & Shareholders & $\begin{array}{l}\text { Customers, } \\
\text { shareholders } \\
\text { (local com- } \\
\text { munities?) }\end{array}$ & $\begin{array}{l}\text { Customers and } \\
\text { high- } \\
\text { performing } \\
\text { employees }\end{array}$ & $\begin{array}{l}\text { Employees (local } \\
\text { communities?) }\end{array}$ \\
\hline $\begin{array}{l}\text { Performance } \\
\text { measurement }\end{array}$ & Growth & Profit & (All) & $\begin{array}{l}\text { Organizational } \\
\text { learning }\end{array}$ & $\begin{array}{l}\text { Growth/organiza- } \\
\text { tional learning }\end{array}$ \\
\hline $\begin{array}{l}\text { Performance } \\
\text { type }\end{array}$ & Productivity & Productivity & Flexibility & Flexibility & Flexibility \\
\hline
\end{tabular}




\section{MANAGEMENT SYSTEM}

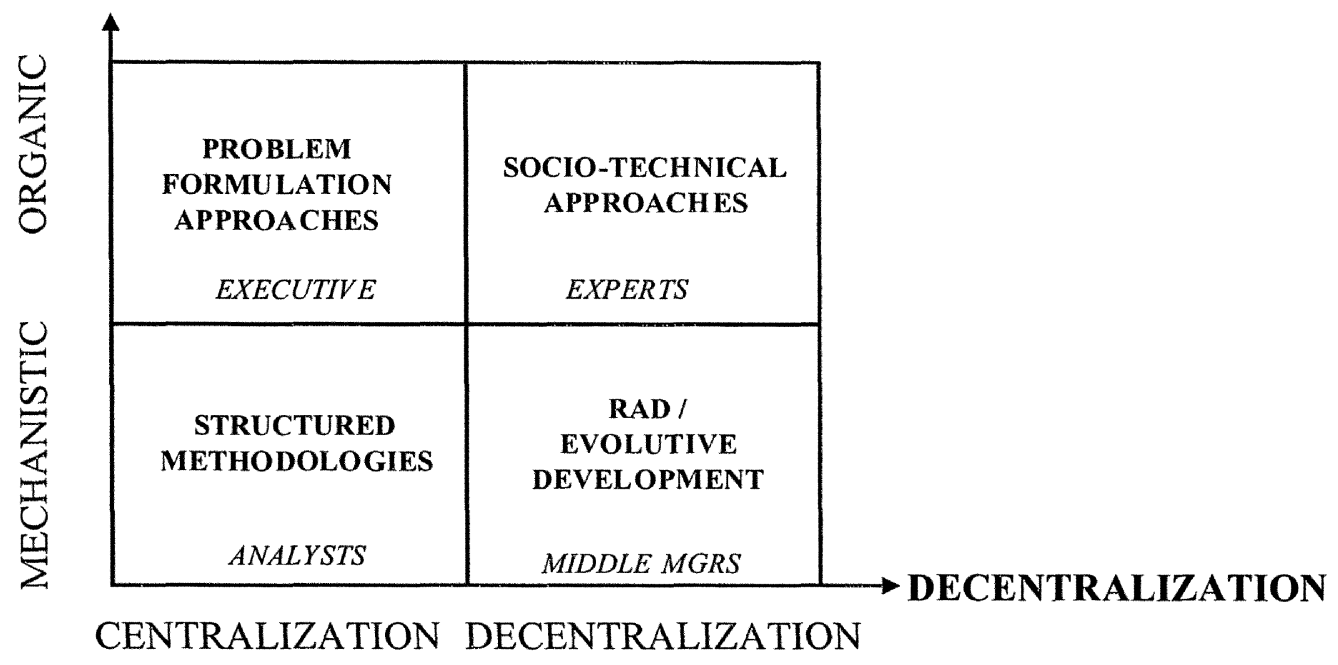

Figure 6. IS Development Method, Actors, Decentralization, and Management System

\subsection{Actors and Linkages to IS Development Methods}

If stakeholders try to impose their preferred structure, what is the consequence on the choice of method for organizational transformation and for IS development? It is through a linkage between method and organizational structure (see Figure 6). Methods mirror organizational structures through their characteristics of process and of content (Monod 1997). The implementation of each IS development method leads to a project that can be analyzed as a kind of organizational structure and methods lend themselves best to particular organizational environments. For instance, structured methodologies themselves are centralized and mechanistic, whereas sociotechnical approaches like ETHICS (Mumford 1983) or Multiview (Avison and Wood-Harper1986) are more decentralized and organic. What this suggests is that the management system of the transformation project is foreshadowed by the management system of the target structure. It is unlikely that one might construct an organic target structure (e.g., entrepreneurial or innovative) with a mechanistic development method (Truex et al. 1999).

\subsection{Actors and Organizational Transformation Methods}

The mirroring of methods and organizational structures extends to organizational transformation methods (Figure 7). Organizational transformation methods lead to management system structures in the transformation project itself. Each actor will be prone to impose the organizational transformation method likely to lead to structures that best serve their interests. 


\section{MANAGEMENT SYSTEM}

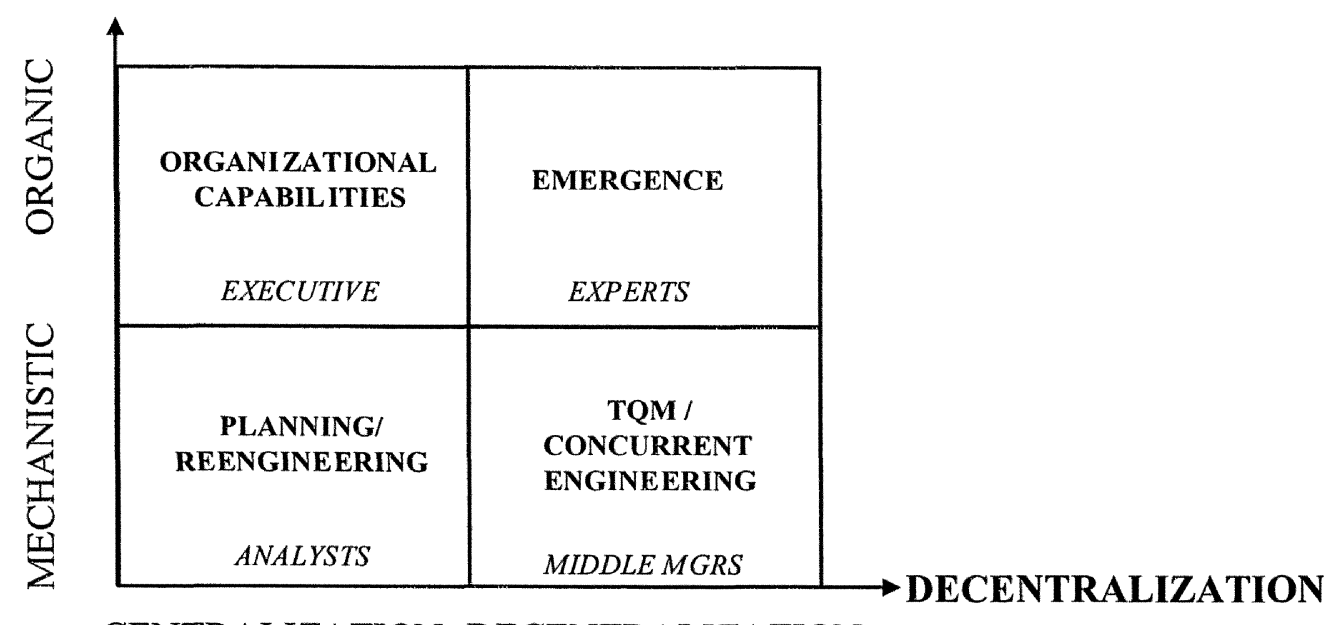

CENTRALIZATION DECENTRALIZATION

Figure 7. Organizational Transformation Method, Actors, Decentralization, and Management System

\section{METHODOLOGY}

By linking the intended discourse of each type of organizational actor to its portrayal of stakeholders and espoused stakeholder interests, organizational theory, performance measurement, IS development, and organizational transformation method (see Figure 1), we can analyze the relationship between the discourse of each organizational actor and each of the stakeholders.

The authors are engaged in ongoing research collecting and examining sets of stakeholder narratives given in organizational actor discourse. The methodology uses history, general hermeneutics, postmodernist sociology, and sociology of action as methodological referents. It arises out of a longitudinal field study and action research project wherein one of the authors was a key member of the reengineering methodology team during the period described in this research. The second author was studying the impact of the reengineering process in one manufacturing and design setting as part of his dissertation research. Thus the various sources and points of contemporaneous observation have the unusual advantage of having a top-down and a bottom-up perspective.

As in all historical analysis, this research relies on numerous sources. We do not refer to these sources simply as data because that connotes something more sterile and less of a messy human construction. We prefer the more classical reference to sources, which are the various productions of social action including art, architecture, and texts (Cassirer 1947; Langer 1953). These sources are considered both individual and societal creations. Applying this notion to organizational history, the actor is both the product and the producer 
of history (Mason et al. 1997). The discourse analysis here is based mainly on internal and confidential texts. The primary documents are a Customer Relationship Reengineering White Paper signed by CEO Gerstner in 1994, the worldwide internal journal Think, and confidential internal transparency presentations also signed by the IBM CEO or his key staff. Direct observations have also been conducted by one of the authors as the planning manager of the CRM (customer relationship management) reengineering in IBM Corporation in the U.S. in 1993 and 1994.

We more narrowly focus on identifying and analyzing a single set of toplevel management narratives; namely, those claiming to be representative of different organizational stakeholders. We also use the sociology of action (Touraine 2000) to illustrate how discourse helps, in the present case, people in key high-level leadership positions in distancing established norms, thus leading to organizational creativity, and the rejection of old rules and stereotypes; with final culmination in the creation of new norms.

This field study is, therefore, both qualitative and longitudinal. In the following section, we propose to describe three phases of discourse created and voiced by the IBM CEO: (1) a discourse about the middle managers in early 1993, (2) a discourse about shareholders during the first phase of the reengineering (customer value management or CVM), and (3) a discourse about the employees during the second phase of the reengineering (CRM).

\section{THE FIELD STUDY}

\subsection{The CEO Discourse About Middle Managers}

In April 1993, the IBM board of directors appointed a new CEO. Mr. Gerstner, the first CEO from outside the firm, replaced the previous CEO, John Ackers, who had been dismissed because of the declining financial results of the Corporation. Beginning in 1991 and for the first time in its history, IBM's net financial performance was negative. This event sent shock waves through its industry. Upon his appointment, Mr. Gerstner spent three months listening to all of his chief officers, including divisional and functional unit heads as well as the chiefs of the various international operations. In his first official announcement following the initial review period, he concluded that IBM's problems arose from decentralized and highly independent operations in which there was no cross functional interaction that might leverage IBM's talents and economies of scale. Thus the discourse, as initially set and expressed by Mr. Gerstner, quickly became a discourse about middle management fiefdoms, and flawed organizational and performance measures. 
We examine this discourse from the perspective of the structure, the performance measurement and the methods advocated by middle managers.

\subsubsection{Structural Assessment}

The CEO's discourse mainly appears in the quarterly worldwide internal magazine Think. Think had been a mainstay at IBM almost from its inception. However, the former CEO had suppressed the journal in the late 1980s. His rationale was that such an internal communication published from main headquarters and in English contradicted his policy to foster decentralization and independent operations by smaller corporate units. Mr. Gerstner revived Think in 1993. The first reconstituted issue talks about a "new IBM" and defines a set of very general principles. Initially each division interpreted those principles freely so they might defend their own interests. Statements like "the market is the driving force behind everything we do" were sometimes interpreted and operationalized as "we must work more with the customer and less internally." While the world expected Mr. Gerstner to lay down explicit plans and establish the new IBM strategy, he refused to do so. He opted to wait laying down general principles and listened to the recommendations filtering up from the ranks.

Will IBM be a service company? A PC company? Will it become a worldwide company? An affirmative answer to the first question would mean to declare war on the hardware divisions. Becoming a personal computer company suggested big trouble for the mainframe division, the midrange systems division, the software divisions, and the service divisions. Becoming a worldwide company would mean definitely separating IBM U.S. and the IBM Corporation, therefore giving more power to the European operating units, which had been yielding more revenue than IBM U.S. beginning in the late 1980s. The IBM partition is linked to internal conflicts between product divisions (mainframe, workstations, PCs, soft, services), between geographical divisions (Asia vs. North America, Europe vs. North America, Italy vs. France, and so on), and between the various functional units such as marketing and sales, finance, administration, and manufacturing.

\subsubsection{Performance Measurement}

During this period, IBM corporate performance measures were short-term oriented. The last corporate 5-year strategic plan had been conducted in 1989, and the long range planning process was officially explicitly abandoned in 1993. The rationale for abandoning long range planning was that the environment was changing too rapidly to make long range strategic planning feasible. The director of strategy in IBM France declared in 1993: 
We are an enterprise unable to invest and move....Anything that takes more than one year is impossible to do (Interview Notes May 1993).

Resources, especially the IS resources, were increasingly being devoted to control activities. Those activities were already over-computerized compared to the customer related activities. Almost all internal investment was oriented toward the strengthening of the "control hydra" that monopolized the lion's share of the IS investment budget. The only justification allowed for IS investment until 1989 was the internal rate of return. Despite attempts to include a new competitive or strategic justification for new IS development, only IS projects that had a computable breakeven point of less than 2 years were considered. The focus had become on productivity rather than on flexibility.

\subsubsection{Methods}

At the level of corporate organization, process improvement methods were based on total quality management (TQM), yet the technique was generally seen as a failure. World Vice-President of Quality and Reengineering Wilson Lowery wrote,

There were few links between divisions... [neither] among them and between countries. This is why TQM was unable to bring back IBM to competitiveness (Think 1994, p. 6).

Under the TQM plan, each function was separately optimized to the detriment of cross-functional linkages. Coordination was attempted through the normalization of results. On the IS development side, only structured methodologies were officially used (Axial, SADDT, Merise). IBM France general management concluded in 1989 that the most strategic processes were the least likely to be computerized (Monod and Rowe 1993). Yet those same processes were also the most cross-functional. Thus the firm held onto methods that did not support critical cross-functional processes.

\subsubsection{Analysis}

This discourse corresponds to the archetype (Figure 8) in which middle management: (1) imposes performance measurement based on productivity, (2) advocates a divisional structure and a decentralized and mechanistic management system, and (3) recommends total quality management methods and structured methodologies, and where (4) control is held by the middle managers 


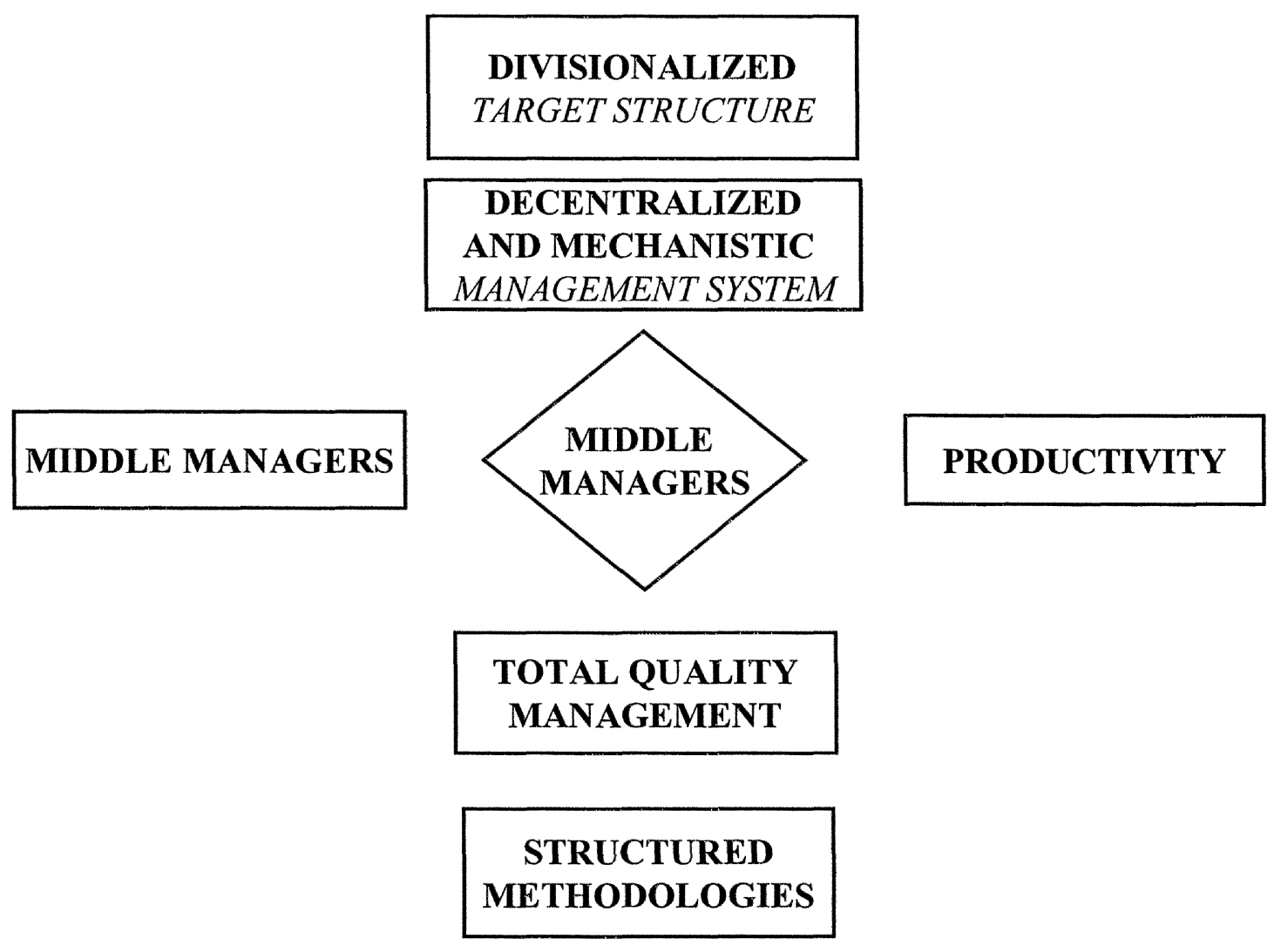

Figure 8. The Discourse of Middle Managers

themselves. The voices that dominate this discourse are those of the middle managers, heard on their own behalf as stakeholders.

\subsection{The CEO Discourse About Stakeholders}

After completing his 3-month assessment in which CEO Gerstner determined that IBM's primary problems arose from creation of functional fiefdoms being held and run by middle managers, the CEO's discourse focused on reengineering as a solution to IBM's malaise. The emphatic justification used to engage in the corporate reengineering plan was to protect shareholder interests. The following is a summary of the CEO discourse about shareholders. Again we use the framework of performance measurement, structure, and methods.

\subsubsection{Performance Measurement}

To provide a clearer picture of corporate performance for the shareholder, corporate productivity metrics were to be represented for IBM as a whole rather than being targeted at the divisional level. While the metric continued as one of 
productivity (i.e., return on investment) it would only be measured at the global level of the corporation. With this cumulative corporate analysis, IBM reported net results as culminating in a loss of almost $\$ 8.9$ billion. Between 1990 and 1993, the stock value had dropped by two-thirds reflecting poor performance and the financial market's adjusted expectations for IBM's future. The first article in the special issue on reengineering in Think opens as follows:

First stop the bleeding. Next lose weight. Then, build up muscle again....A year and a half ago, the company was hemorrhaging cash, awash in the red ink of quarterly losses and writeoff....That's the origin of the goal to cut $\$ 7$ billion out of IBM's expense structure by 1986 , since revisited to $\$ 8$ billion (p. 4).

\subsubsection{Methods}

The twin financial objectives, of returning to profitability and of stemming the red ink, were met through headcount reduction. The number of IBM employees was cut from 383,000 employees in 1989, to 301,000 in 1992, 256,000 in 1993 , and finally to 220,000 in 1994 . But running an enterprise with half of the workforce became problematic, a point acknowledged by CEO Gerstner: "Headcount reduction alone was not sufficient. Additional reduction would have been counter-productive" (p. 1).

Thus CEO Gerstner decided, in September 1993, to continue the reengineering by "reducing the low value work" (p. 1), without any further headcount reduction. With this pronouncement, reengineering adopted a performance measurement that relinked the return of the global level of the corporation with the productivity of local units. With this change, local units were to retask themselves from a divisional orientation to a cross-functional process orientation. Moreover, as we shall see below, the idea was also to redirect the firm to a more customer-centric way of seeing the business.

In order to continue the savings in structure costs, nine reengineering project have been launched at the worldwide level. Among these nine projects, Customer Relationship Management (CRM) (marketing and sales processes) require the biggest workload on each continent (p. 2).

The first round of CRM reengineering (although initially called customer value management or CVM) was launched in late 1993. The objective was to reduce the high level of sales expenses, but reengineering "found that IBM Marketing and Sales (as opposed to Manufacturing and Development) spent \$7.8 billions for CRM" (p. 3). 
Reengineering teams met in Thornwood, New York, and started designing processes and the related IS to support the newly designed processes. These teams focused on process modeling with its output being process diagrams. These diagrams were translated into written procedures manuals, called rule books. The assumption was that the divisional operational units were going to change their ways of working via reference to these rules books. The CVM reengineering was implemented in the United States in late 1993.

The reengineering was a complete failure. Operational units flatly refused to fall in line, insisting instead that they must have not rule books but tools kits for flexibility and redesign. In effect they demanded IS tool support and flexible guidelines and principles versus rigid rules.

\subsubsection{Structure}

A simple diagnosis for this failure would have been employee or unit resistance to change. We believe that the reason was more complex and relates to the interests and proclivities of the analysts. Phase one (CVM) failed because the reengineering teams of pure analysts were devoted only to financial interests. The new management system was centralized in New York and was top-down directed. It was a hierarchical and nonparticipative design. Its approach was mechanistic because organizational coordination was supposed to be performed through rules and procedures. The employees resisted and recognized the CVM as a form of a new Taylorism. Much of the process redesign work 1993 was targeted at "uniformization" of all operations through standardization of processes.

Once redesigned, we will implement best practices and their supporting integrated information systems in a uniform way across the four geographic units of IBM Marketing and Services (p. 1).

\subsubsection{Analysis}

This discourse corresponds to the archetype (Figure 9) in which analysts and executives (1) claim to represent the analysts and shareholders as stakeholders, (2) argue for performance measurement based on productivity, (3) indicate through the reengineering a functional structure, and (4) imply a traditional methodology for systems development and a reengineering structure for managing the organizational transformation project. The voices that dominate this discourse are those of the analysts and executives heard on behalf of shareholders as stakeholders. 


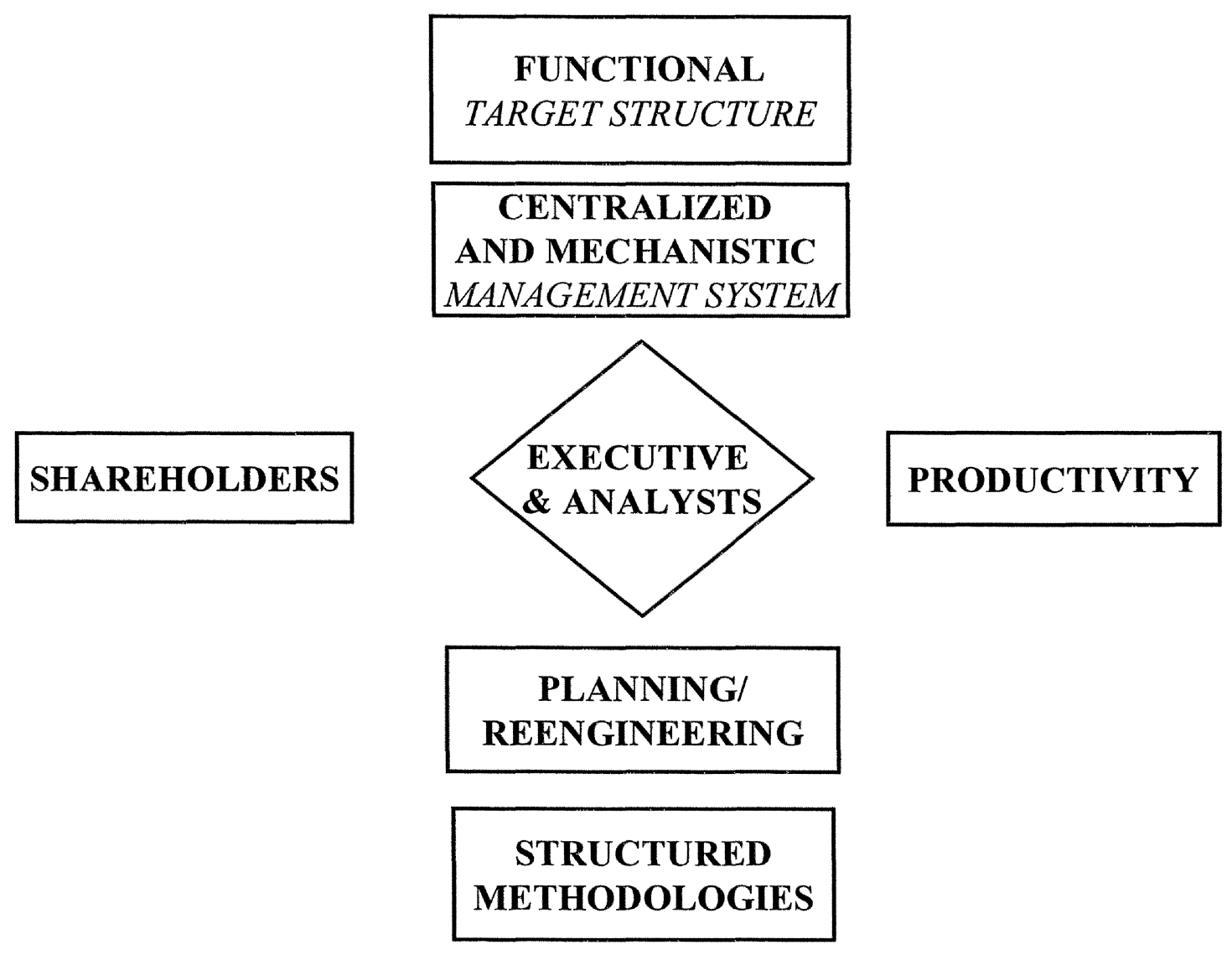

Figure 9. Executive and Analysts Discourse

\subsection{The Discourse About Employees and Customers}

The CVM failure provided ammunition to opponents to the reengineering method as the means for organizational transformation. The analysts who had been advocating for the reengineering methods lost power. This opened the door for other stakeholders to command the ear of the CEO. These other stakeholders were high performing and expert employees and customers. Their influence was reflected in changing performance measures, structures, and methods within the CEO discourse. The CEO's discourse evolved once again in 1994. We next present a description and analysis of this newly evolved discourse.

\subsubsection{Performance Measurement}

The critical goal of returning to profitability was addressed through headcount reductions and supplementing profits with one time income realization though the sale of real estate and defunct divisions. The sale of non- 
performing units was part of the objective to reduce low value work. By ridding themselves of units marginal to the overall bottom line, IBM realized quick income, which it used to show a quick turnaround. But clearly staff reductions and sales of business units and properties were not sustainable practices in a going concern, so after addressing the objectives of "stopping the hemorrhaging" and "losing weight," in 1994 attention was turned to a third objective; namely, to "rebuild a musculature." In an internal White Paper, CEO Gerstner writes:

During last years, we made great progress in size reduction of our workforce and in the creation of an expense structure more competitive.... Nevertheless, those reductions contributed to the decline of our customer satisfaction and of our revenue....We must reduce our workload and change the way we approach markets (p. 1).

The rebuilding of musculature required that IBM reposition itself significantly. In an internal white paper entitled Customer Relationship Management, Mr. Gerstner demonstrated that 70 percent of IBM activities were in declining off-the-rack markets while only 15 percent of its activities were in growing mass-customization markets. The dynamic adaptation required for masscustomization implied a radical transformation of IBM structures and processes. Therefore, the primary IBM performance metric was going to have to evolve from one of productivity to one of flexibility.

\subsubsection{Structure}

The management system, only inferred in the first phase of the reengineering process, became more explicit when the aims were clearly defined to redesign the sales and sales support practices such that CRM could respond to customer changes. Sales and support would become more specialized, responsible and accessible with better IT applications for tailoring unique solutions for customers. With an emphasis on an environment for teamwork and sharing, the management system was clearly becoming decentralized and organic. Freer access to information was an essential part of the IS redesign aim and the coordination mechanism is mutual adjustment between professionals (employees).

This final goal state is described in the last page of the white paper: "we will have created an environment for teamwork and sharing" (p. 24). A greater willingness for knowledge sharing is stressed:

We must capitalize on opportunities by leveraging the sharing, of information, skills and intellectual capital created during 
these engagements, between geographies and divisions of IBM (p. 5).

Therefore, the structural objectives changed from creating structures privileging productivity toward creating one that enhances flexibility. The target structure was to be innovative.

\subsubsection{Methods}

During this period, both reengineering and information systems development (ISD) methods changed radically. They became user-driven, based on emergence for organizational transformation and on socio-technical methods for IS development. Cooperation became a watchword. Vice-President of Reengineering for North America, Robin Sternbergh, wrote of the previous era:

Nobody came to say us "don't cooperate," but this is how things went in IBM Marketing and Services. There are probably many reasons for that: geographic fiefdoms, ancient conventions systems, risk aversion. But there is only one way to improve things: reengineering (Think 1994, p. 9).

CEO Gerstner underscored the new ethic of internal cooperation:

If I learn that somebody refused to contribute to a customer request, he had better hide deep in the ground (Personal Notes from a worldwide internal satellite conference to all employees, March 1993).

\subsubsection{Analysis}

This discourse corresponds to the archetype (Figure 10) as follows: (1) it claims to represent the employees and customers as stakeholders, (2) it argues for performance measurement based on flexibility, (3) it advocates for a decentralized and organic management system (innovative structure), and (4) it recommends and capitalizes on sociotechnical approaches for IS development and an emergence method for organizational transformation. The voices that dominate this discourse are those of the executives and experts heard on behalf of customers and employees as stakeholders. 


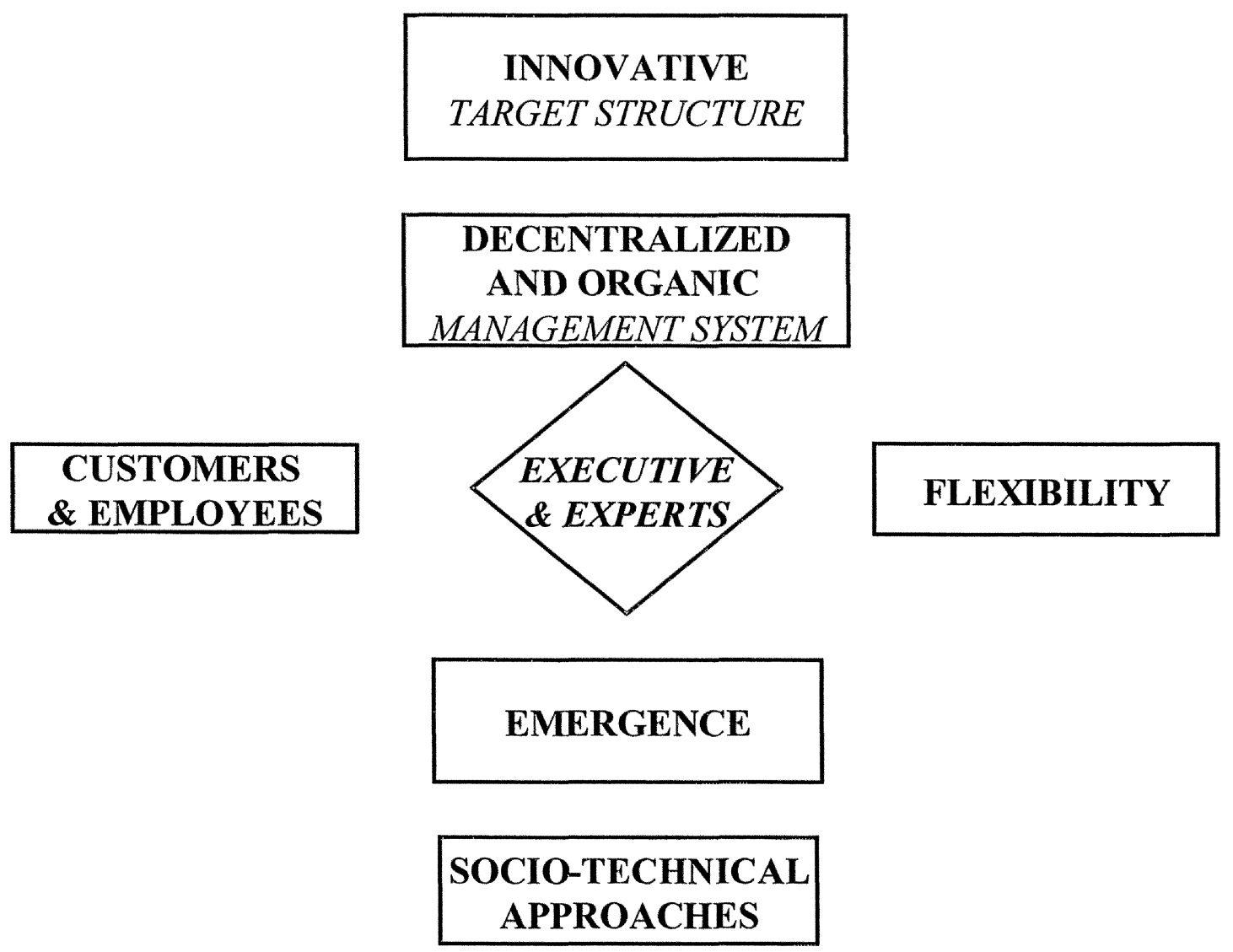

Figure 10. Executive and Experts Discourse

\section{RETROSPECTIVE}

This research encounters the classical limits of any historical and hermeneutic enterprise. In selecting a 2-year period out of a 30-year history, we are picking up a snapshot of a continuing process of transformation and restructuring in midstream. Another methodological limit is that the research presented here rests on only three primary textual sources: a confidential internal document, confidential presentations, and an internal corporate journal, Think. It also relies on direct observations and interviews conducted by one of the authors.

Still, we clearly saw in the IBM reengineering case that the creation of a new norm always foreshadowed a structure that best serves the interests of a given stakeholder (e.g., the functional structure for the shareholder, the innovative structure for the customers, etc.). The analysis of the IBM reengineering case describes actors surrounded by political forces. The CEO's attitude illustrated his willingness to steadfastly maintain that he was indeed the shareholder advocate in 1993, and then to morph into the customer advocate in 1994. 
In organization theory, there is an opposition between rational decision theory and garbage can (Cohen et al. 1972) overtaken by the structure theory of Mintzberg (1979). This opposition has its counterpart in sociology, that is, between interactionism, doing away with any reference to social norms in the course of the exchange, and sociological determinism, which reduces change to the confrontation with an enemy (a cultural transformation imposed from outside). The combination of postmodernist analysis of discourse as shaped by external powers (Foucault 1972) and the sociology of action (Touraine 2000) allows us to resolve this opposition. The sociology of action questions how the departure from established norms leads to organizational creativity, the rejection of old rules, and finally the creation of new norms.

One the one hand, this case represents criticism of classical rational decision theory (Simon 1977), which holds that there exists a decision maker who considers all relevant decision options, chooses the best available option, and initiates required action to implement the decision. The authors found contradictory evidence to this process in the present case. The case illustrates a political process in the discourse that is constantly being influenced by internal and external forces. One the other hand, we also noted that the discourse was not entirely shaped by outside forces (Foucault, 1972). Rather like the various events and institutional forces that shaped the American President's decision (e.g., the U.S. Navy versus the U.S. Air Force) during the Cuban missile crisis, (Allison 1971). Lou Gestner was the central actor in a political maelstrom. In identifying organizational actors as being internal political forces but also being forces linked to external actors, such as customers and shareholders, we have broadened the scope of the garbage can model.

By considering the CEO's shifting discourse from the combined perspectives of interactionalism and sociological determinism, it doesn't matter whether the behavior was manipulative, opportunistic, or manipulated by the outside. It also illustrates how some views were privileged in the discourse while others, however important, were never heard at all. The CEO does not speak for all stakeholders and does not act as if he was the agent of all stakeholders: for instance, he does not mention rank and file employees, government, or local communities, nor were they explicitly considered in the process of the reengineering. Stakeholder agency theory naturally leads to a contextual interpretation: the discourse is more under the influence of external forces than under the control of the author.

It is likely these external forces have elements of a darker and more tragic side in which villains resisted survival and where innocents were sacrificed to a greater good. It is a story in which whole communities were laid waste in a battle of survival and lives were irrevocably changed, some for the worse. These discourses could be discovered in future research that incorporates missionary organizational structures and local communities. Such an expansion would 
encompass the experiences of stakeholders who did not survive the transition, people who by choice or by enforced departure left the organization in the midst of its survival throes. Still others may come from within the regional communities that were deeply affected by the transformation of a great manufacturing corporation into a bird of a different feather, an organization retasked to a greater service orientation.

\section{REFERENCES}

Allison, G. T. The Essence of Decision: Explaining the Cuban Missile Crisis. Boston: Little Brown, 1971.

Ansoff, H. I. Corporate Strategy. New York: McGraw-Hill, 1962.

Argyris, C., Putnam, R., and Smith, D. Action Science. San Francisco: Jossey-Bass, 1990.

Argyris, C., and Schön, D. Organizational Learning: A Theory of Action Perspective. Reading, MA: Addison-Wesley, 1978.

Avison, D. E., and Wood-Harper A. T. "Multiview: An Exploration in Information Systems Development," Australian Computer Journal (18:4), November, 1986, pp. 174 - 179.

Bennis, W. Beyond Bureaucracy: Essays on the Development and Evolution of Human Organization. San Francisco: Jossey-Bass, 1993.

Burns, T., and Stalker, G. M. The Management of Innovation. London: Tavistock, 1961.

Cassirer, E. An Essay on Man: An Introduction to a Philosophy of Human Culture. New Haven, CT: Yale University Press, 1947.

Chandler, A. D. Strategy and Structure: Chapters in the History of the Industrial Enterprise. Cambridge, MA: MIT Press, 1962.

Cohen, M. D., March, J. G., and Olson, J. P. "A Garbage Can Model of Organizational Choice," Administrative Science Quarterly (17:1), March, 1972, pp. 1-25.

Davis, G. B. "Strategies for Information Requirements Determination," IBM Systems Journal (21:1), 1982, pp. 4-30.

Derrida, J. (ed.). Différance: Margins of Philosophy. Chicago: University of Chicago Press, 1982.

Derrida, J. "Structure, Sign and Play in the Discourse of Human Sciences," in Writing and Difference (trans. A. Bass). Chicago: University of Chicago Press, 1978, pp. 278-293.

Foucault, M. The Archaelogy of Knowledge. New York: Pantheon Books, 1972.

Galbraith, J. R. Organization Design. Reading, MA: Addison-Wesley, 1977.

Galbraith, J. R. Competing with Lateral Flexible Organizations ( ${ }^{\text {nd }}$ ed.). Reading, MA: Addison-Wesley, 1994.

Hills, C., and Jones, T. "Stakeholder-Agency Theory," Journal of Management Studies (29:2), March 1992, pp. 131-153.

Jensen, M., and Meckling, W. "The Theory of the Firm: Managerial Behavior, Agency Costs, and Ownership Structure," Journal of Financial Economics (3), 1976, pp. 305-360.

Langer, S. K. An Introduction to Symbolic Logic. New York: Dover Publications, Inc., 1953.

Mason, R. O., McKenney, J. L., and Copeland, D. G. "An Historical Method for MIS Research: Steps and Assumptions," MIS Quarterly (21:3), September 1997, pp. 307-320.

Mintzberg, H. Mintzberg on Management: Inside Our Strange World of Organizations. New York: The Free Press, 1989.

Mintzberg, H. The Structuring of Organizations: A Synthesis of the Research. Englewood Cliffs, NJ: Prentice Hall, 1979. 
Monod, E. "Effectiveness of IS Development: The IBM Case," Systèmes d'Information et Management (12:1), 1997, pp. 40-55.

Monod, E., and Rowe, F. "Justification of IS Investment," Proceedings of the IDATE Conference: Investing in communication (Investir dans la communication), France Telecom, Montpellier, France, 1993.

Mumford, E. Designing Human Systems for New Technology: The Ethics Method. Manchester, England: Manchester Business School Publishing, 1983.

Nadler, D., and Tushman, M. Strategic Organization Design: Concepts, Tools, Process. New York: Scott Foresman and Co., 1988.

Schleiermacher, F. Hermeneutics: The Handwritten Manuscripts (H. Kimmerle, Ed.; J. Duke and J. Forstman, Trans.). Missoula, MT: Scholar Press, 1977

Sommerville, I., and Sawyer, P. Requirements Engineering: A Good Practice Guide. Chichester, England: John Wiley \& Sons, 1997.

Toffler, A. Future Shock. New York: Bantam Books, 1970.

Touraine, A. "A Method for Studying Social Actors," Journal for World Systems Research (1), Fall/Winter, 2000, pp. 900-918.

Truex, D. P., Baskerville, R., and Klein, H. K. "Growing Systems in an Emergent Organization," Communications of the ACM (42:8), August 1999, pp. 117-123.

\section{About the Authors}

Emmanuel Monod has served as an associate professor in Information Systems at the University of Nantes (France) since 1996. Emmanuel has published 14 refereed journal articles, transactions, and book chapters primarily in the French academic journals Systèmes d'Information et Management and Réseaux (Networks). His research specializations are the organizational impacts of IS, systems analysis and design, electronic commerce, and epistemology and philosophy. Prior to joining the University, he was a manager for IBM in France and the U.S. for six years, and served two years each with France Télécom and with COFACE (La Companie Francaise du Commerce Exterieur). He holds his $\mathrm{Ph} . \mathrm{D}$. from National School of Telecom of Paris. He is the Vice-President of the French national IS association (AIM), which is officially affiliated with the Association for Information Systems (AIS). He will be a Visiting Associate Professor in the CIS Department at Georgia State University beginning in January 2003. Emmanuel can be reached by e-mail at monod@sc-eco.univnantes.fr.

Duane Truex is interested in the social impacts of information systems development, particularly in the impact on workers and how the emergent properties of organizations may be reflected in emergent ISD approaches. He has studied enterprise-wide IS development issues in Canada, the U.S., and abroad. Duane is active in the IFIP 8.2 research community, a member of the editorial board of Information Systems Journal, and coeditor of the special issue on Enterprise Resource Planning Systems: A Critical View for The Database for Advances in Information Systems. He is currently an assistant professor of 
Information Systems at Florida International University, a Leverhulme Research Fellow in the United Kingdom at the University of Salford, England, a visiting Full Research Professor at Aalborg University, Denmark, and a Visiting Professor in the College of Information and Management, University of Nantes, France. Duane can be reached by e-mail at duane.truex@fiu.edu.

Richard L. Baskerville is a professor of information systems and chairman in the Department of Computer Information Systems, at Georgia State University. His research specializes in security of information systems, methods of information systems design and development, and the interaction of information systems and organizations. His interests in methods extend to qualitative research methods. He is former chair of IFIP Working Group 8.2, and a Chartered Engineer under the British Engineering Council. Baskerville holds degrees from the University of Maryland (B.S. summa cum laude, Management), and the London School of Economics, University of London (M.Sc., Analysis, Design and Management of Information Systems, abd Ph.D., Systems Analysis). Richard can be reached by e-mail at baskerville@acm.org. 